\title{
PREVALENSI ASPERGILLUS FUMIGATUS PADA PENJUAL KACANG TANAH DAN JAGUNG KOTA BENGKULU
}

\author{
Leni Marlina, Halimah, Susiwati \\ Politeknik Kesehatan Kementerian Kesehatan Bengkulu, Jurusan Analis Kesehatan, \\ Jalan Indragiri No. 3 Padang Harapan Bengkulu 38225 \\ leni_zuhri75@yahoo.com
}

\begin{abstract}
Aspergillus fumigates infection in peanut and corn sellers may arise due to the behavior of sellers of raw food materials which is not good. The behavior of how the storage and use of raw food materials and Personal Protective Equipment (PPE), is a behavior that must be considered. PPE is a self-protection tool that can be used for work in order to protect themselves and others, while the storage method is the treatment of raw food materials. The purpose of this study was to determine the Aspergillus fumigates infection associated with peanut and corn seller behavior in market town of Bengkulu.This research is an analytic survey research using cross-sectional design. In this study, the population was the whole peanut and corn seller in the market of Bengkulu were 30 people. Samples in Panorama Market were 10 sellers of peanuts and 5 corn sellers. The data was collected using primary data on the presence or absence of the fungus Aspergillus fumigates in seller's sputum which obtained from laboratory tests. Then performed a collection of data about how to storage and use of masks by observation. Data analysis was done analytically using the chi-square test.The results showed the majority (53.3\%) prevalence of the fungus Aspergillus fumigates. There was a significant correlation between the behavior of the storage of peanuts and corn and the use of masks by the behavior of sellers in the market of Bengkulu. There is no determinant highly influential on the cause of the two variables.For the merchant of peanut and corn should further enhance self-protection such as the use of appropriate PPE in order to avoid infection fungal pathogens such as Aspergillus fumigates.
\end{abstract}

Keywords: Aspergillus fumigates, storage, Personal Protective Equipment (PPE)

Abstrak: Infeksi Aspergillus fumigatus pada penjual kacang tanah dan jagung terjadi karena perilaku penjual bahan baku pangan yang kurang baik. Cara penyimpanan bahan pangan dan penggunaan pelindung diri (APD), merupakan perilaku yang harus diperhatikan. APD seperti masker dipakai selama bekerja agar dapat melindungi diri dari infeksi melalui udara. Cara penyimpanan merupakan perlakuan bahan pangan agar terhindar tumbuhnya jamur. Tujuan penelitian ini untuk mengetahui infeksi jamur A. fumigatus dikaitkan dengan perilaku penjual kacang tanah dan jagung di pasar kota Bengkulu. Penelitian ini merupakan survei dengan pendekatan cross sectional. Responden adalah 30 orang, yaitu semua penjual kacang tanah dan jagung di pasar Kota Bengkulu. Identifikasi ada tidaknya jamur A. fumigatus pada sputum penjual merupakan data primer yang diperiksa di laboratorium. Kemudian pengumpulan data tentang cara penyimpanan dan pemakaian masker (APD) oleh penjual dengan cara observasi. Hasil penelitian dianalisis secara statistic, yaitu diperoleh sebagian besar (53\%) prevalensi infeksi jamur Aspergillus fumigatus. Ada hubungan yang bermakna antara perilaku cara penyimpanan kacang tanah dan jagung dan perilaku pemakaian masker oleh para penjual di pasar kota Bengkulu. Tidak ada determinan yang sangat berpengaruh pada dua variabel penyebab tersebut. Diperlukan sosialisasi temuan penelitian ini agar para pedagang kacang tanah dan jagung lebih meningkatkan proteksi diri seperti penggunaan APD yang tepat agar terhindar dari infeksi jamur patogen A. fumigates.

Kata Kunci Aspergillus fumigatus, Cara Penyimpanan, Alat Pelindung Diri (APD) 
Kacang tanah dan jagung adalah bahan yang mengandung karbohidrat, protein dan lemak baik yang cukup tinggi, oleh karena itu kacang tanah dan jagung dapat menjadi sumber energi. Banyak masyarakat yang menyukainya karena rasanya yang enak. Tetapi, kacang tanah dan jagung selama dalam penyimpanan dapat terserang kapang (jamur). Kapang dapat menurunkan kualitas biji, mengubah warna biji, menurunkan kandungan nutrisi dan menghasilkan mikotoksin. Biji kacang tanah dan jagung kaya akan nutrisi sehingga merupakan substrat yang baik bagi pertumbuhan kapang. Pertumbuhan kapang disebabkan oleh tingginya kadar air pada pangan dan kualitas biji saat pemanenan dan penanganan pascapanen (Bahri, 2001). Salah satu dari kapang ialah Aspergillus fumigatus.

Cemaran kapang Aspergillus fumigatus banyak ditemui di Indonesia dan untuk infeksi yang ditimbulkannya sudah lazim terjadi seperti penyakit Aspergillosis Paru (Zainuddin, 2009). Kejadian penyakit ini tersebar di seluruh dunia, tetapi kasusnya lebih sering didiagnosis di negara-negara tropis seperti Indonesia terutama pada saat cuaca panas dan lembab. Perkembangan spora jamur sangat didukung dengan kondisi lingkungan, pada situasi faktor-faktor lingkup di sekitarnya banyak dijumpai material yang mendukung maka spora tersebut akan dengan mudah mengkontaminasi, baik terbawa oleh angin kemudian terhirup oleh manusia ataupun mengkonsumsi pangan yang telah tercemar (Hananto, 2012).

Perilaku penjual dalam mengolah dan menangani bagaimana bahan baku pangan ini terbebas dari infeksi kapang berperan penting merupakan perilaku preventif dari manusia. Kapang tumbuh pada penyimpanan dengan kelembabam tinggi dan bertemperatur tinggi. Penyimpanan di ruangan yang kelembabannya tinggi ( $>80 \%$ ) dan dalam karung dapat mempercepat laju pertumbuhan kapang. Daerah tropis merupakan tempat berkembang biak kapang paling ideal termasuk Aspergillus fumigatus. Penelitian ini bertujuan untuk mengetahui infeksi jamur Aspergillus fumigatus dikaitkan dengan perilaku penjual ka- cang tanah dan jagung di pasar kota Bengkulu.

\section{BAHAN DAN CARA KERJA}

Penelitian ini merupakan survei analitik dengan pendekatan Cross Sectional. Pengukuran perilaku penjual terhadap penyimpanan hasil pertanian dan penggunaan APD dengan cara mengobservasi dan pemeriksaan sputum penjual dilakukan pada waktu yang sama. Identifikasi jamur A. fumigatus dilakukan di Laboratorium Terpadu Politeknik Kesehatan Kementerian Kesehatan Bengkulu. Populasi adalah semua penjual kacang tanah dan jagung di pasar Kota Bengkulu pada dua pasar, yaitu Pasar Panorama Kota Bengkulu dan Pasar Minggu Kota Bengkulu. Pasar Panorama 10 penjual kacang tanah dan 5 penjual jagung, di pasar Minggu 7 penjual kacang tanah dan 8 penjual jagung. Sampel yang diteliti yaitu sputum penjual kacang tanah dan jagung. Sputum yang diambil adalah sputum sewaktu sebanyak 30 sampel sputum yang dijadikan sampel penelitian.

Pemeriksaan jamur A. fumigatus pada sampel sputum dilakukan secara mikroskopis dengan metode pemeriksaan langsung. Sampel yang merupakan sputum penjual diperiksa di bawah mikroskop dengan lensa obyek 40x yang sebelumnya obyek glass sudah ditetesi $\mathrm{KOH} 20 \%$. Data tentang cara penyimpanan dan pemakaian masker (APD) oleh penjual dikumpulkan dengan cara observasi.

\section{HASIL}

Analisis Univariat

Tabel 1. Distribusi Frekuensi Infeksi Jamur, Cara Penyimpanan dan Alat Pelindung Diri Variabel Frekuensi Persentase (30) $\quad(100 \%)$

\begin{tabular}{lcc} 
Aspergillus fumigatus & & \\
Positif & 16 & 53,3 \\
Negatif & 14 & 46,7 \\
Cara simpan & & \\
Tidak baik & 22 & 73,3 \\
Baik & 8 & 26,7 \\
Alat pelindung Diri & & \\
Tidak masker & 19 & 63.3 \\
Ya masker & 11 & 36,7 \\
\hline
\end{tabular}


Hasil analisis pada tabel 1 diperoleh sebagian besar $(53,3 \%)$ penjual kacang tanah dan jagung di Pasar Kota Bengkulu terinfeksi jamur Aspergillus fumigatus, sebagian besar $(73,3 \%)$ cara simpan yang tidak baik, dan sebagian besar $(63,3 \%)$ tidak menggunakan APD (masker).

\section{Analisis Bivariat}

Tabel 2. Hubungan Perilaku Cara Penyimpanan Kacang Tanah dan Jagung dan Pemakaian Masker dengan Infeksi Jamur Aspergillus fumigatus

\begin{tabular}{|c|c|c|c|c|c|c|c|}
\hline \multirow{3}{*}{ Variabel } & \multicolumn{5}{|c|}{$\begin{array}{c}\text { Jamur Aspergillus } \\
\text { fumigatus }\end{array}$} & \multirow[b]{3}{*}{$p$} & \multirow{3}{*}{ OR } \\
\hline & \multicolumn{2}{|c|}{ Positif } & \multicolumn{2}{|c|}{ Negatif } & \multirow{2}{*}{$\begin{array}{c}\mathbf{n} \\
(\%) \\
\end{array}$} & & \\
\hline & $f$ & $\%$ & f & $\%$ & & & \\
\hline \multicolumn{8}{|c|}{ Penyimpanan } \\
\hline Tidak Baik & 15 & 68,2 & 7 & 31,8 & $\begin{array}{c}22 \\
(100)\end{array}$ & 0,012 & 15.0 \\
\hline Baik & 1 & 12,5 & 7 & 87,5 & $\begin{array}{c}8 \\
(100)\end{array}$ & & \\
\hline \multicolumn{8}{|c|}{ Pemakaian APD } \\
\hline Tidak & 16 & 84,2 & 3 & 15,8 & $\begin{array}{c}19 \\
(100)\end{array}$ & 0,000 & \\
\hline Ya & 0 & 0 & 11 & 100 & $\begin{array}{c}11 \\
(100)\end{array}$ & & \\
\hline
\end{tabular}

Hasil analisis bivariat pada tabel 2 dapat diketahui bahwa dari 22 responden yang menyimpan kacang tanah dan jagung tidak baik sebanyak $15(68,2 \%)$ responden menderita infeksi jamur Aspergillus fumigatus. Uji statistik didapatkan nilai $\rho=0,012<\alpha(0,05)$, berarti ada hubungan yang signifikan antara perilaku cara penyimpanan kacang tanah dan jagung dengan infeksi jamur Aspergillus fumigatus pada penjual kacang tanah dan jagung di Pasar Kota Bengkulu Tahun 2013 dimana penyimpanan yang tidak baik berisiko 15 kali untuk terinfeksi jamur Aspergillus fumigatus (OR:15,00).

Dari tabel 2 dapat diketahui bahwa dari 19 responden tidak menggunakan alat pelindung diri (masker) sebanyak $16(84,2 \%)$ responden menderita infeksi jamur Aspergillus fumigatus. Dari uji tersebut didapatkan nilai $\rho$ $=0,000<\alpha(0,05)$, berarti ada hubungan yang signifikan antara pemakaian alat pelindung diri masker dengan infeksi jamur Aspergillus fumigatus pada penjual kacang tanah dan jagung di Pasar Kota Bengkulu.

Analisis Multivariat
Tabel 3. Determinan Cara Simpan dan Alat Pelindung Diri terhadap Infeksi Aspergillus fumigatus

\begin{tabular}{lccccc}
\hline Variabel & B & SE & $\boldsymbol{p}$ & OR & 95\% CI \\
\hline $\begin{array}{l}\text { Alat PD } \\
\text { Cara }\end{array}$ & 22.466 & 1146 & 0.998 & $5.713 \times 10^{9}$ & $0.000---$ \\
Simpan & 2.015 & 1.602 & 0.209 & 7.5 & $0.325-173.283$ \\
\hline
\end{tabular}

Setelah dilakukan analisis multivariat pada tabel 3 terlihat bahwa dari kedua variabel alat pelindung diri pedagang dan cara simpan pedagang terhadap kacang dan jagung tidak ada yang berpengaruh terhadap infeksi Aspergillus fumigatus arena memberikan nilai $\rho>0,05$ sehingga tidak ada variabel yang dominan pengaruh pada kejadian infeksi Aspergillus fumigatus pada sputum pedagang.

\section{PEMBAHASAN}

\section{Infeksi $A$. fumigatus}

Hasil penelitian didapatkan sebagian besar penjual kacang tanah dan jagung di Pasar Kota Bengkulu terinfeksi jamur Aspergillus fumigatus. Nilai ini merupakan nilai prevalensi infeksi Aspergilus fumigatus yang menunjukkan bahwa sebagian besar ditemukannya Aspergillus fumigatus pada sputum penjual kacang tanah dan jagung yang dijual di Pasar Kota Bengkulu.

Aspergillus fumigatus adalah salah satu jenis jamur atau kapang yang sering mengkontaminasi makanan. Aspergillus fumigatus merupakan jamur yang biasa tumbuh pada hasil panen yang mengandung minyak, misalnya kacang-kacangan, jagung, cabe, biji kapas dan serealia.

Penyimpanan di ruangan yang kelembabannya tinggi (>80\%) dan di dalam karung dapat mempercepat laju pertumbuhan kapang. Daerah tropis merupakan tempat berkembang biak paling ideal. Kondisi daerah tropika yang lembab dapat memacu tumbuh dan berkembang berbagai hama dan penyakit, termasuk Aspergillus fumigatus yang merupakan kapang yang dikenal dapat menginfeksi paru-paru manusia sehingga menimbulkan penyakit Aspergillosis Paru.

Manifestasi klinis Aspergillosis dapat berupa respons allergik, kolonisasi Aspergillus spesies, invasif Aspergillosis dan dissemi- 
nated Aspergillosis. Setelah Candidiasis, Aspergillosis merupakan infeksi jamur oportunistik kedua jenis penyakit yang sering dijumpai pada pasien immunokompromais. Pada individu immunokompromais, inhalasi spora jamur Aspergillus dapat menyebabkan infeksi yang invasif pada paru maupun sinus dan sering diikuti perluasan infeksi secara hematogen ke organ lain. Namun individu non immunokompromais, inhalasi spora jamur $A s$ pergillus dapat menyebabkan infeksi yang terlokalisir pada paru, sinus ataupun pada tempat lain (Dillon, 2002).

Penyakit aspergillosis paru disebabkan karena terhirup spora jamur melalui inhalasi dalam jangka waktu yang lama. Penggunaan APD sangat berperan penting dalam mencegah infeksi salah satunya adalah pentingnya penggunaan masker oleh penjual kacang tanah dan jagung yang setiap harinya berkecimpung dengan bahan pangan tersebut. Namun, masyarakat di Indonesia khususnya para penjual bahan pangan cenderung tidak biasa memakai APD seperti masker dalam aktivitas jual-beli. Oleh karena itu, kecenderungan terinfeksinya tubuh oleh jamur patogen seperti Aspergillus fumigatus akan berpeluang besar.

Sejalan dengan penelitian Lewis et al., (2005), dilaporkan terjadinya wabah aflatoksikosis akut yang luas di penduduk Kenya propinsi bagian timur dan menyebabkan kematian sekitar 400 kasus. Wabah ini terjadi akibat konsumsi maize (jagung) yang tercemar aflatoksin. Tingginya jumlah kasus dan luasnya area yang terlibat kemungkinan akibat aflatoksin yang mencemari maize beredar melalui sistem distribusi regional (pasar).

\section{Cara Penyimpanan Kacang Tanah dan Jagung}

Hasil penelitian menunjukan sebagian besar cara penyimpanan tidak baik. Hal ini menunjukkan bahwa sebagian besar cara penyimpanan kacang tanah dan jagung tidak baik. Penyimpanan hasil pertanian merupakan bagian yang penting dalam penanganan paska panen. Beberapa jenis hasil pertanian sangat rentan terhadap kerusakan selama penyimpanan, apalagi jika sistem penyimpanan yang ditetapkan kurang atau tidak memenuhi persyaratan penyimpanan yang baik. Proses perubahan biokimia dan serangan agen-agen perusak dapat menyebabkan susut dan menghasilkan metabolit yang berbahaya bagi kesehatan selama penyimpanan. Oleh karena itu, perlu dilakukan penyimpanan yang baik dan benar. Dalam hal ini, perlu dilakukan kontrol terhadap faktor-faktor lingkungan yang berperan dalam penyimpanan serta kontrol terhadap agen-agen yang dapat menimbulkan kerugian.

Penyimpanan hasil pertanian membutuhkan lingkungan yang mendukung kondisi yang dapat mempertahankan hasil pertanian dalam waktu lama dengan tidak mengubah kualitas dan kuantitas hasil pertanian (tidak mengubah rasa, warna, bentuk, dan sebagainya) serta mencegah terjadinya perkecambahan terutama dalam penyimpanan hasil pertanian yang berbentuk biji-bijian. Hal ini dapat dilakukan dengan mengendalikan temperatur, kelembapan, komposisi gas dalam udara, dan pengendalian hama yang dapat merusak hasil pertanian (Rokhani, 2009).

\section{Alat Pelindung Diri}

Hasil penelitian diperoleh sebagian besar tidak menggunakan Alat Pelindung Diri (masker). Di Indonesia dewasa ini sudah mulai berkembang tingkat peridustriannya. APD untuk mengurangi resiko kecelakaan dalam pekerjaan terutama di industri. APD adalah seperangkat alat yang digunakan oleh tenaga kerja untuk melindungi seluruh/sebagian tubuhnya terhadap kemungkinan adanya potensi bahaya/kecelakaan kerja. APD dipakai sebagai upaya terakhir dalam usaha melindungi tenaga kerja apabila usaha rekayasa (engineering) dan administratif tidak dapat dilakukan dengan baik (Toni, 2012).

Alat pelindung pernafasan adalah alat yang penting, mengingat $90 \%$ kasus keracunan sebagai akibat masuknya bahan-bahan kimia saluran pernapasan. Masker tujuannya melindungi membran mukosa hidung dan mulut selama melakukan tindakan suatu pekerjaan yang memungkinkan terjadi percikan atau terhirupnya suatu unsur mikroba sehingga dapat menimbulkan penyakit (Satria, 2011). 
Hubungan Cara Penyimpanan Kacang Tanah dan Jagung dengan Infeksi Aspergillus fumigatus

Penyimpanan hasil pertanian merupakan bagian yang penting dalam penanganan paska panen, apalagi jika sistem penyimpanan yang ditetapkan kurang atau tidak memenuhi persyaratan penyimpanan yang baik. Oleh karena itu, perlu dilakukan penyimpanan yang baik dan benar. Dalam hal ini, perlu dilakukan kontrol terhadap faktor-faktor lingkungan yang berperan dalam penyimpanan erta kontrol terhadap agen-agen yang dapat menimbulkan kerugian. Penyimpanan hasil pertanian membutuhkan lingkungan yang mendukung kondisi yang dapat mempertahankan mutu pangan dalam waktu lama dengan tidak mengubah kualitas dan kuantitas hasil pertanian dengan tidak mengubah rasa, warna, bentuk, dan sebagainya.

Dari hasil analisis menunjukkan bahwa ada hubungan yang signifikan antara perilaku cara penyimpanan kacang tanah dan jagung dengan infeksi jamur Aspergillus fumigatus pada penjual kacang tanah dan jagung di Pasar Kota Bengkulu. Setelah dilakukan peninjauan lebih lanjut tentang cara penyimpanan kacang tanah di pasar kota Bengkulu, didapatkan bahwa kacang tanah dan jagung disimpan dalam karung pada ruang penyimpanan yang memiliki kelembaban besar yaitu lebih dari $80 \%$. Penerangan yang kurang (gelap) disebabkan oleh kurangnya oksigen atau udara yang masuk ke dalam ruang penyimpanan. Hal ini akan mempengaruhi mutu hasil pertanian tersebut dan ini memberikan peluang besar pada kacang tanah dan jagung dengan cepat dan mudah terinfeksi jamur pathogen, salah satunya Aspergillus fumigatus.

Hal ini sesuai dengan teori yang dikemukakan oleh Rokhani (2009), penyimpanan hasil pertanian yang buruk dapat memicu pertumbuhan jamur yang dapat merusak bahan hasil pertanian dan menyebabkan penyakit pada manusia yaitu Aspergillosis. Aspergillus secara umum terdapat di lingkungan sekitar, sehingga banyak orang menghirup spora jamur setiap hari terutama pada penjual kacang tanah dan jagung di pasar. Penyebaran Aspergillus fumigatus melalui terhirupnya spora Aspergillus fumigatus yang terdapat di udara.
Pedagang yang selalu kontak dengan kacang tanah atau jagung mustahil untuk terhindar dari spora Aspergillus. Orang-orang dengan sistem kekebalan tubuh yang sehat tidak menyebabkan kerusakan dan sistem kekebalan tubuh mampu menyingkirkan spora, tetapi orang dengan sistem kekebalan tubuh lemah dapat menyebabkan infeksi. Penelitian lain telah menunjukkan bahwa Aspergillosis invasif dapat terjadi selama renovasi bangunan atau konstruksi. Penelitian ini sesuai dengan penelitian yang dilakukan oleh Oramahi et al., (2009), ada pengaruh kelembaban relative dan suhu terhadap aktivitas glukoamilase $A s$ pergillus.

Sejalan dengan penelitian Lewis et al., (2005), wabah aflatoksikosis akut yang luas di antara penduduk Kenya propinsi bagian timur dan menyebabkan kematian sekitar 400 kasus. Wabah ini terjadi akibat konsumsi maize (jagung) yang tercemar aflatoksin. Peristiwa ini timbul berkaitan dengan musim hujan yang datang pada waktu yang tidak biasa yaitu pada saat panen sehingga maize hasil panen yang masih basah dan belum cukup kering ini yang disimpan di lumbunglumbung menjadi lembab. Keadaan ini menyebabkan terjadinya pertumbuhan jamur sehingga toksinnya mencemari hasil panen tersebut.

\section{Hubungan Pemakaian Alat Pelindung Diri (Masker) dengan Infeksi Aspergillus fumigatus}

Alat pelindung diri (APD) adalah suatu alat yang mempunyai kemampuan untuk melindungi seseorang yang fungsinya mengisolasi sebagian atau seluruh tubuh dari potensi bahaya di tempat kerja. APD dipakai sebagai upaya terakhir dalam usaha melindungi tenaga kerja apabila usaha rekayasa (engineering) dan administratif tidak dapat dilakukan dengan baik (Toni, 2012).

Hasil analisis menunjukkan bahwa ada hubungan yang signifikan antara perilaku pemakaian alat pelindung diri (masker) dengan infeksi jamur Aspergillus fumigatus pada penjual kacang tanah dan jagung di Pasar Kota Bengkulu. 
Hal ini sesuai dengan teori yang dikemukakan oleh Satria (2011), alat pelindung pernafasan adalah alat yang penting mengingat $90 \%$ kasus keracunan sebagai akibat masuknya bahan-bahan kimia saluran pernafasan. Masker tujuannya melindungi membran mukosa hidung dan mulut, selama melakukan tindakan suatu pekerjaan yang memungkinkan terjadi percikan atau terhirupnya suatu unsur mikroba sehingga dapat menimbulkan penyakit. Penggunaan Alat Pelindung Diri sangat berperan penting dalam mencegah infeksi salah satunya adalah pentingnya penggunaan masker oleh penjual kacang tanah dan jagung yang setiap harinya berkecimpung dengan bahan pangan tersebut. Namun, masyarakat di Indonesia khususnya para penjual bahan pangan cenderung tidak biasa memakai APD seperti masker dalam aktivitas pasarnya. Oleh karena itu, kecenderungan terinfeksinya tubuh oleh jamur patogen seperti Aspergillus fumigatus akan berpeluang besar.

Infeksi jamur Aspergillus fumigatus ini dapat terjadi ketika para penjual yang tidak menggunakan masker ketika bekerja terhirup oleh spora dari jamur ini dalam jangka waktu yang lama. Spora jamur yang mengkontaminasi kacang tanah dan jagung yang kemudian terhirup oleh pedagang, dan spora ini masuk ke dalam paru-paru.

Penggunaan APD yang tepat dapat dilakukan guna mengurangi resiko terinfeksi dari jamur pathogen ini. Selain itu, penanganan dan penyimpanan bahan baku hasil pertanian harus diperhatikan agar bahan pangan tersebut tidak mudah terkontaminasi jamur yang dapat menyebabkan penyakit pada manusia.

Determinan cara simpan dan alat pelindung diri terhadap infeksi Aspergillus fumigatus

Hasil analisis multiariat menunjukan tidak ada pengaruh pada kedua faktor penye- bab yaitu cara simpan dan penggunaan alat pelindung diri dari pedagang meskipun saat dihubungkan satu-satu penyebab memberikan hubungan yang bermakna. Infeksi Aspergillus fumigatus pada sputum pedagang hasil panen tersebut dapat disebabkan udara dengan kontak langsung dengan hasil panen yang sudah terinfeksi Aspergillus fumigatus.

\section{KESIMPULAN}

Penelitian ini dapat disimpulkan sebagian besar $(53,3 \%)$ penjual kacang tanah dan jagung di Pasar Kota Bengkulu terinfeksi jamur Aspergillus fumigatus, sebagian besar $(73,3 \%)$ cara simpan yang tidak baik, dan sebagian besar $(63,3 \%)$ tidak menggunakan APD (masker). Ada hubungan yang bermakna antara perilaku cara penyimpanan kacang tanah dan jagung dan perilaku pemakaian masker oleh para penjual di pasar kota Bengkulu. Tidak ada determinan yang sangat berpengaruh pada dua variabel penyebab tersebut.

Peneliti memberikan saran kepada Kepala Dinas Perindustrian dan Perdagangan (Disperindag) Kota Bengkulu perlunya melakukan pembinaan dan pengawasan terhadap para pedagang kacang tanah dan jagung di pasaran, dan memberikan informasi tentang bahayanya jamur patogen yang dapat mencemari bahan baku pangan sehingga dapat meningkatkan pengawasan dan pembinaan tentang cara penyimpanan dan pentingnya pemakaian APD masker terhadap penjual dipasaran. Kepada Pedagang Kacang Tanah dan Jagung agar pedagang kacang tanah di pasaran hendaknya lebih meningkatkan proteksi diri seperti penggunaan APD yang tepat agar terhindar dari infeksi jamur pathogen seperti Aspergillus fumigatus.

\section{DAFTAR RUJUKAN}

Anonim, 2002. Mewaspadai Cemaran Aflatoksin pada Pangan. Dimuat dalam http://www.google.co.id/url?sa=t\&rct=j\&q=\&es $\mathrm{rc}=\mathrm{s} \&$ source $=$ web $\& \mathrm{~cd}=2 \& \mathrm{ved}=0 \mathrm{CE} 0 \mathrm{QFj} \mathrm{AB} \&$ url=http $\% 3 \mathrm{~A} \% 2 \mathrm{~F} \% 2 \mathrm{Fbalitnak}$.litbang.deptan.g o.id, diakses tanggal 1 November 2012.

Bahri, S. 2001. Mewaspadai Cemaran Mikotoksin pada Pakan dan Produk Peternakan di 
Indonesia. Laporan Teknik Tahun 2001. Balai Penelitian Besar Veteriner. Bogor.

Hananto, 2012. Aspergillosis. Dimuat dalam http://www.novindo.co.id/index.php?option=co m_content\&view=article\&id=28:transmisiAspergillosis, diakses tanggal 7 Juni 2013.

Lewis L, et al. 2005. Aflatoxin contamination of commercial maize products during an outbreak ofacute aflatoxicosis in Eastern and Central Kenya: Environ Health Perspect.

Oramahi, et al. 2009. Pengaruh Kelembapan Relatif dan Suhu Terhadap Aktivitas Glukoamilase Aspergillus. Jurnal HPT Tropika.Vol. 9 no.1:6772.

Rahmianna et al. 2007. Cemaran Aflatoksin B1 pada Kacang Tanah yang Diperdagangkan di Sentra Produksi Banjarnegara. Balai Penelitian
Tanaman Kacang-Kacangan dan Umbi-Umbian. Malang.

Rokhani, H. 2009. Pengendalian Lingkungan Dalam Bangunan Pertanian. Departemen Teknik Mesin dan Biosistem Institut Pertanian Bogor. Bogor .

Satria. 2011. Manfaat Masker. Dimuat dalam http://satriawan35.blogspot.com/2012/06/skripsi -tentang-manfaat-masker-di-rsud.html, diakses tanggal 8 Juni 2013.

Toni. 2012. Alat Pelindung Diri. Dimuat dalam http://tonimpa.wordpress.com/2013/04/25/maka lah-alat-pelindung-diri-apd/, diakses tanggal 8 Juni 2013.

Zainuddin, AR. 2009. Cemaran Kapang pada Pakan dan Pengendaliannya. Laporan Teknik Tahun 2009. Balai Penelitian Besar Veteriner. Bogor. 